\title{
DYSPROSIAN XENOTIME-(Y) FROM THE ANNIE CLAIM \#3 GRANITIC PEGMATITE, SOUTHEASTERN MANITOBA, CANADA: EVIDENCE OF THE TETRAD EFFECT?
}

\author{
MORGAN MASAU, PETR ČERNÝ§ AND RON CHAPMAN \\ Department of Geological Sciences, University of Manitoba, Winnipeg, Manitoba R3T 2N2, Canada
}

\begin{abstract}
Dysprosian xenotime-(Y) was found in the Annie Claim \#3 pod of lepidolite-subtype granitic pegmatite within the Greer Lake intrusion of pegmatitic granite, in the Archean Bird River Subprovince of the Superior Province, in southeastern Manitoba. It occurs as microscopic inclusions in spessartine and as discrete crystals, both enclosed in ferroan muscovite, also associated with manganocolumbite - manganotantalite, microlite, zircon and apatite. The xenotime-(Y) contains up to 14.88 wt. $\%$ Dy $2 \mathrm{O}_{3}$ (and 7.59 wt. $\% \mathrm{Gd}_{2} \mathrm{O}_{3}, 3.31$ wt. $\% \mathrm{~Tb}_{2} \mathrm{O}_{3}$ ), the highest concentration of Dy so far observed in this mineral. In chondrite-normalized REE patterns, the positive Tb anomaly is even higher than that of Dy. Along with xenotime- $(\mathrm{Y})$ and xenotime- $(\mathrm{Yb})$ from other granitic pegmatites, altered granites and alpine veins, the Annie Claim \#3 xenotime-(Y) shows prominent double segmenting of the Gd to Lu sequence, ascribed by some authors to the tetrad effect in geological materials generated from, or affected, by aqueous media. Analytical problems could not produce this effect in the xenotime samples.
\end{abstract}

Keywords: xenotime-(Y), xenotime-(Yb), rare-earth elements, tetrad effect, granitic pegmatite, Annie Claim \#3, Manitoba, Canada.

\section{SOMMAIRE}

Nous avons trouvé du xénotime-(Y) enrichi en dysprosium dans une lentille de pegmatite granitique de type lépidolite appelée Annie Claim \#3, et faisant partie du massif intrusif du lac Greer, d’âge archéen, Sous-province de Bird River de la Province du Supérieur, dans le secteur sud-est du Manitoba. Les cristaux se présentent en inclusions dans la spessartine et en cristaux distincts, tous inclus dans des agrégats de muscovite ferreuse, en association avec manganocolumbite - manganotantalite, microlite, zircon et apatite. Le xénotime-(Y) contient jusqu'à $14.88 \% \mathrm{Dy}_{2} \mathrm{O}_{3}$ en poids (et $7.59 \% \mathrm{Gd}_{2} \mathrm{O}_{3}, 3.31 \% \mathrm{~Tb}_{2} \mathrm{O}_{3}$ ), la teneur de Dy la plus élevée qui soit connue pour cette espèce. Les spectres de terres rares normalisés par rapport à une distribution chondritique montrent une anomalie positive en Tb même plus grande que l'anomalie en Dy. Comme c'est le cas pour le xénotime-(Y) et le xénotime-( $\mathrm{Yb}$ ) provenant d'autres pegmatites granitiques, granites altérés et veines alpines, le xénotime-(Y) de la pegmatite Annie Claim \#3 fait preuve d'une segmentation double des teneurs normalisées dans l'intervalle entre Gd et Lu, que certains ont attribué à l'effet de tétrade, reconnu dans les matériaux déposés à partir de milieux aqueux, ou bien affectés par ceux-ci. Les problèmes analytiques ne sauraient expliquer cet effet dans les échantillons de xénotime.

(Traduit par la Rédaction)

Mots-clés: xénotime-(Y), xénotime-(Yb), terres rares, effet de tétrade, pegmatite granitique, Annie Claim \#3, Manitoba, Canada.

\section{INTRODUCTION}

Xenotime-(Y) normally shows low contents of heavy rare-earth elements (HREE) and negligible concentrations of their light counterparts ( $L R E E$ ). Increased quantities of individual HREEs, such as those in xenotime(Yb) (Buck et al. 1999), are exceptional, although moderate enrichment in $\mathrm{Yb}$, Dy and Gd has been occasionally noticed (Vlasov 1966, Sahama et al. 1973,
Franz et al. 1996). Here we report on the occurrence of xenotime-(Y) with the highest content of Dy ever reported in this mineral, from a lepidolite-subtype granitic pegmatite in Manitoba. This example of xenotime-(Y) also shows potential evidence, along with some of its pegmatitic and hydrothermal counterparts, of the controversial tetrad effect in chondrite-normalized $R E E$ patterns.

§ E-mail address: p_cerny@umanitoba.ca 


\section{Regional Setting And the Parent Pegmatite}

The parent pegmatite is located in southeastern Manitoba, very close to the southwestern margin of the Greer Lake pegmatitic granite, located in metabasalts of the Lamprey Falls Formation of the Bird River Greenstone Belt, in the Bird River Subprovince, western Superior Province of the Canadian Shield [ $c f$. Černý et al. (1981) for details of regional geology].

The pegmatite forms a subellipsoidal, subhorizontal body approximately $10 \times 7$ meters in size, with distinct concentric zoning (Masau 1999). The zones show an inward progression of five main types of mica, from muscovite to lithian muscovite and lepidolite, associated mainly with quartz and several varieties of albite; $\mathrm{K}$-feldspar is subordinate in the outermost zones and missing in the intermediate and inner zones. Accessory minerals include spessartine, cesian beryl, cassiterite, manganocolumbite, manganotantalite and rare microlite, uranpyrochlore, wodginite, ferrotapiolite, yttrotantalite or formanite-(Y), apatite, zircon, coffinite, uraninite and xenotime-(Y). Minerals of boron and phosphates of $\mathrm{Li}, \mathrm{Al}, \mathrm{Fe}$ or $\mathrm{Mn}$ are conspicuously absent.

The Dy-enriched xenotime-( $\mathrm{Y})$ forms inclusions in garnet $\left(\mathrm{Sps}_{64} \mathrm{Alm}_{29} \mathrm{Grs}_{7}\right.$ to $\mathrm{Sps}_{83} \mathrm{Alm}_{11} \mathrm{Grs}_{6}$, with up to 0.67 wt. $\% \mathrm{Y}_{2} \mathrm{O}_{3}$ ), which is hosted by small subround nodules of dark brownish green ferroan muscovite (2.21 to 7.57 wt. \% total $\mathrm{Fe}$ as $\mathrm{FeO}, 0.04$ to 0.33 wt.\% $\mathrm{MnO}$, 0.58 to 1.66 wt. $\% \mathrm{Rb}_{2} \mathrm{O}$, average $\mathrm{Li}_{2} \mathrm{O} 0.63$ wt.\%). The mica aggregates also contain discrete crystals of dysprosian xenotime-(Y), and subhedral platy crystals of manganocolumbite-manganotantalite $[\mathrm{Mn} /(\mathrm{Mn}+\mathrm{Fe})$ at. from 0.44 to $0.87, \mathrm{Ta} /(\mathrm{Ta}+\mathrm{Nb})$ at. from 0.18 to $0.85]$, in part replaced by microlite. Isolated grains of the xenotime-(Y) are rarely found scattered among the mica flakes. The paragenetic position of the micaceous nodules could not be precisely established, as they were found only in broken-up dump material. However, the nodules most probably crystallized in late stages of consolidation of the Annie Claim \#3 pegmatite, as they locally cross-cut adjacent albite of the outer intermediate zone.

\section{EXPERIMENTAL}

The dysprosian xenotime-(Y) was analyzed using a Cameca SX-50 electron microprobe at the Department of Geological Sciences, University of Manitoba. The conditions of analysis in the wavelength-dispersion mode were the same as those applied to xenotime-( $\mathrm{Yb})$ by Buck et al. (1999), except for an accelerating voltage of $15 \mathrm{kV}$ and a beam current of $20 \mathrm{~mA}$. The analytical data were reduced and corrected by the PAP method of Pouchou \& Pichoir $(1884,1985)$. The values of Tm were adjusted for overlap with Sm using the method of Åmli \& Griffin (1975), elaborated on by Nagy (1993), and processed by the XMAS option for overlap deconvolution. $\mathrm{Zr}, \mathrm{Hf}, \mathrm{Al}, \mathrm{Sc}$ and $\mathrm{Ce}$ (and, in most cases, La also) were found to be below detection limits; Pr and Eu were not sought. All of the minor Fe was assumed divalent.

Chondritic REE values of Taylor \& McLennan (1985) were used to normalize the REE contents of xenotime$(\mathrm{Y})$ and xenotime-( $\mathrm{Yb})$ from all localities cited.

\section{Dysprosian Xenotime}

The subhedral to anhedral inclusions of xenotime$(\mathrm{Y})$ in garnet embedded in micaceous aggregates range from 20 to $10 \mu \mathrm{m}$ in size, and the xenotime-(Y) grains disseminated in those aggregates are somewhat larger, $\leq 150 \mu \mathrm{m}$. Internally, most of the grains are homogeneous, or they display only minor variations in the cation contents. Distinctly heterogeneous distribution of $\mathrm{Y}$ and the individual HREE is rarely observed.

Representative compositions of the Annie Claim \#3 xenotime-(Y) are shown in Table 1 . The content of Dy is variable, between 6.90 and 14.88 wt. $\% \mathrm{Dy}_{2} \mathrm{O}_{3}$, and averaging about $8.5 \mathrm{wt} . \%$. The $14.88 \mathrm{wt} . \%$ concentration is the highest ever observed; it amounts to 0.17 atoms per formula unit (apfu), alongside the dominant $\mathrm{Y}$ at 0.66 . Gadolinium also is enriched at $7.59 \mathrm{wt} \%$ oxide and $0.09 a p f u$. In contrast, the incorporation of $\mathrm{Si}, \mathrm{U}$ and Th is negligible, and $\mathrm{Zr}$ may be present, if at all, only below detection limits of electron microprobe. Thus, departure of the compositions toward the coffinite and thorite components is not important, and a potential zircon component is undetectable. Also, the satisfactory analytical totals and stoichiometry of unit formulas indicate that the potential presence of hydroxyl must be negligible, even lower than that of the fluorine (maximum 0.31 wt.\%, $0.032 a p f u$, and much less in all other compositions).

\section{DisCUSSION}

\section{Absolute REE concentrations}

Slight selective enrichment in Dy was reported in xenotime-(Y) by Demartin et al. (1991) from granitic pegmatites and alpine veins, by Förster \& Rhede (1995), Sabourdy et al. (1997) and Förster (1998) from granites, and by Franz et al. (1996) from metapelites. However, concentrations of Dy comparable to those reported in xenotime-(Y) from the Annie Claim \#3 have not been so far encountered in any environment. Representative data quoted in Table 1 (compositions 1 to 4) are shown graphically in Figure 1A, using the style favored by, e.g., Vlasov (1966): the sum of even-numbered medium and heavy REE, complemented by Y, is normalized to a total of 100. This representation reflects the absolute abundances of individual $R E E+\mathrm{Y}$ relative to each other.

Table 1 also lists representative $\mathrm{Yb}$-enriched compositions quoted by Jefford (1962), Voloshin \& Pakhomovskii (1986), Belolipetskii \& Voloshin (1996) 
TABLE 1. REPRESENTATIVE COMPOSITIONS OF DYSPROSIAN XENOTIME-(Y)

FROM THE ANNIE CLAIM \#3 GRANITIC PEGMATITE

AND OF OTHER DY-, Yb-, AND Gd-ENRICHED SAMPLES

\begin{tabular}{|c|c|c|c|c|c|c|c|c|c|c|c|c|c|c|c|}
\hline & 1 & 2 & 3 & 4 & 5 & 6 & 7 & 8 & 9 & 10 & 11 & 12 & 13 & 14 & 15 \\
\hline $\mathrm{P}_{2} \mathrm{O}_{5}$ & 36.73 & 35.43 & 35.13 & 33.92 & 34.90 & 32.60 & 33.57 & 33.64 & 32.90 & 31.80 & 29.46 & 27.25 & 29.03 & 28.82 & 24.47 \\
\hline $\mathrm{SiO}_{2}$ & 0.12 & 0.03 & 0.04 & 0.00 & 0.00 & 1.00 & 0.27 & 0.68 & 0.26 & 0.74 & 2.93 & n.d. & n.d. & 0.00 & n.d. \\
\hline $\mathrm{ZrO}_{2}$ & n.d. & n.d. & n.d. & n.d. & n.d. & n.d. & n.d & s.d. & n.d. & n.d. & 2.66 & n.d. & n.d. & n.d. & n.d. \\
\hline $\mathrm{ThO}_{2}$ & 0.00 & 0.00 & 0.22 & 0.44 & 0.30 & 0.10 & 0.8 & .75 & 0.00 & 0.84 & 0.95 & n.d. & n.d. & 0.00 & n.d. \\
\hline $\mathrm{Al}_{2} \mathrm{O}_{3}$ & n.d. & n.d. & n.d. & n.d. & n.d. & n.d. & n.d. & n.d. & n.d. & n.d. & 2.00 & n.d. & n.d. & n.d. & n.d. \\
\hline $\mathrm{Fe}_{2} \mathrm{O}_{3}$ & n.d. & n.d. & n.d. & n.d. & n.d. & n.d. & n.d. & n.d. & n.d. & n.d. & 0.35 & n.d. & n.d. & n.d. & n.d. \\
\hline $\mathrm{UO}_{2}$ & 0.27 & 0.17 & 0.02 & 0.37 & 1.00 & 0.20 & 0.21 & 0.26 & 0.32 & 0.25 & 0.22 & n.d. & n.d. & n.d. & n.d. \\
\hline $\mathrm{Y}_{2} \mathrm{O}_{3}$ & 48.93 & 41.87 & 39.73 & 34.79 & 47.50 & 42.90 & 38.97 & 40.57 & 30.40 & 26.80 & 33.99 & 8.75 & 12.51 & 25.28 & 10.32 \\
\hline $\mathrm{La}_{2} \mathrm{O}_{3}$ & 0.00 & 0.00 & 0.00 & 0.00 & n.d. & n.d. & 0.02 & 0.05 & n.d. & n.d. & n.d. & n.d. & n.d. & n.d. & n.d. \\
\hline $\mathrm{Ce}_{2} \mathrm{O}_{3}$ & 0.00 & 0.00 & 0.00 & 0.00 & n.d. & n.d. & 0.00 & 0.11 & 0.00 & 0.06 & n.d. & n.d. & n.d. & n.d. & n.d. \\
\hline $\mathrm{Pr}_{2} \mathrm{O}_{3}$ & n.d. & n.d. & n.d. & n.d. & n.d. & n.d. & 0.00 & 0.01 & 0.03 & 0.04 & n.d. & n.d. & n.d. & n.d. & n.d. \\
\hline $\mathrm{Nd}_{2} \mathrm{O}_{3}$ & 0.07 & 0.20 & 0.00 & 0.00 & n.d. & 0.50 & 0.07 & 0.10 & 0.19 & 0.16 & 0.33 & n.d. & n.d. & n.d. & n.d. \\
\hline $\mathrm{Sm}_{2} \mathrm{O}_{3}$ & 0.00 & 1.19 & 0.29 & 0.73 & n.d. & 1.20 & 1.03 & 0.56 & 0.22 & 0.24 & 0.46 & n.d. & n.d. & 0.26 & n.d. \\
\hline $\mathrm{Eu}_{2} \mathrm{O}_{3}$ & n.d. & n.d. & n.d. & n.d. & 0.10 & 0.10 & n.d. & n.d. & n.d. & n.d. & n.d. & n.d. & n.d. & 0.00 & n.d. \\
\hline $\mathrm{Gd}_{2} \mathrm{O}_{3}$ & 2.29 & 6.38 & 5.78 & 7.59 & 2.40 & 3.50 & 8.60 & 7.34 & 5.43 & 2.71 & 0.90 & 0.26 & 0.23 & 1.36 & 0.09 \\
\hline $\mathrm{Tb}_{2} \mathrm{O}_{3}$ & 1.16 & 1.64 & 2.53 & 3.31 & 0.90 & 0.90 & 1.24 & 1.16 & 1.05 & 0.61 & 0.48 & 0.19 & n.d. & 0.15 & n.d. \\
\hline $\mathrm{Dy}_{2} \mathrm{O}_{3}$ & 6.90 & 8.45 & 11.69 & 14.88 & 7.20 & 6.90 & 6.44 & 6.71 & 8.61 & 5.61 & 5.02 & 3.72 & 3.57 & 5.53 & 0.86 \\
\hline $\mathrm{Ho}_{2} \mathrm{O}_{3}$ & 0.60 & 0.54 & 0.78 & 0.87 & 1.20 & 1.20 & 1.11 & 1.23 & 2.00 & 1.30 & 0.64 & 0.94 & 0.61 & 2.33 & n.d. \\
\hline $\mathrm{Er}_{2} \mathrm{O}_{3}$ & 1.42 & 1.62 & 1.18 & 1.53 & 4.00 & 3.80 & 3.78 & 3.16 & 7.23 & 7.37 & 4.87 & 8.29 & 7.69 & 9.23 & 5.87 \\
\hline $\mathrm{Tm}_{2} \mathrm{O}_{3}$ & 0.21 & 0.27 & 0.20 & 0.11 & n.d. & n.d. & nd. & n.d. & 1.13 & 1.69 & 1.13 & 2.86 & 2.52 & 1.86 & 3.33 \\
\hline $\mathrm{Yb}_{2} \mathrm{O}_{3}$ & 1.07 & 1.62 & 1.00 & 1.07 & 2.20 & 3.00 & 2.68 & 1.85 & 7.82 & 15.10 & 11.73 & 36.37 & 32.27 & 18.69 & 43.38 \\
\hline $\mathrm{Lu}_{2} \mathrm{O}_{3}$ & 0.01 & 0.00 & 0.00 & 0.00 & 0.20 & 0.30 & 0.70 & 0.61 & 1.30 & 2.27 & 0.96 & 7.12 & 9.84 & 2.26 & 8,48 \\
\hline $\mathrm{CaO}$ & 0.00 & 0.03 & 0.03 & 0.13 & 0.00 & 0.10 & 0.03 & 0.09 & 0.08 & 0.17 & n.d. & n.d. & n.d. & 0.15 & 0.24 \\
\hline $\mathrm{FeO}$ & 0.28 & 0.00 & 0.08 & 0.13 & n.d. & n.d. & n.d. & n.d. & n.d. & n.d. & n.d. & n.d. & n.d. & n.d. & n.d. \\
\hline $\mathrm{MnO}$ & 0.00 & 0.00 & 0.13 & 0.00 & n.d. & n.d. & n.d. & n.d. & n.d. & n.d. & n.d. & n.d. & n.d. & n.d. & n.d. \\
\hline $\mathrm{PbO}$ & 0.05 & 0.00 & 0.00 & 0.00 & n.d. & n.d. & n.d. & n.d. & nd. & n.d. & n.d. & n.d. & n.d. & n.d. & n.d. \\
\hline F & 0.03 & 0.06 & 0.00 & 0.00 & n.d. & n.d. & n.d. & n.d. & n.d. & n.d. & n.d. & n.d. & n.d. & n.d. & n.d. \\
\hline $\mathrm{O}=\mathrm{F}$ & -0.01 & -0.03 & 0.00 & 0.00 & n.d. & n,d. & n.d. & n.d. & n.d. & n.d. & n.d. & nd. & n.d. & n.d. & n.d. \\
\hline Total & 100.13 & 99.47 & 98.83 & 99.87 & 101.70 & 98.30 & 99.58 & 98.88 & 98.97 & 97.76 & 99.59 & 95.75 & 98.27 & 95.92 & 97.04 \\
\hline \multicolumn{16}{|c|}{ atoms per formula unit (normalized to 4 anion atoms) } \\
\hline $\mathrm{Zr}$ & - & - & - & - & - & - & - & - & - & - & 0.045 & - & - & - & - \\
\hline Th & 0.000 & 0.000 & 0.002 & 0.003 & 0.002 & 0.001 & 0.007 & 0.006 & 0.000 & 0.007 & 0.008 & - & - & 0.000 & - \\
\hline $\mathrm{U}$ & 0.002 & 0.001 & 0.000 & 0.003 & 0.007 & 0.002 & 0.002 & 0.002 & 0.003 & 0.002 & 0.002 & - & - & - & - \\
\hline $\mathrm{Al}$ & - & - & - & - & - & - & - & - & - & - & 0.082 & - & - & - & - \\
\hline $\mathrm{Fe}^{2+}$ & - & - & - & - & + & - & - & - & - & - & 0.009 & - & - & - & . \\
\hline $\mathrm{Y}$ & 0.839 & 0.747 & 0.718 & 0.645 & 0.835 & 0.789 & 0.717 & $0.74 !$ & 0.581 & 0.527 & 0.630 & 0.202 & 0.272 & 0.534 & 0.248 \\
\hline $\mathrm{La}$ & 0.000 & 0.000 & 0.000 & 0.000 & - & - & 0.000 & 0.001 & - & - & - & - & - & - & - \\
\hline $\mathrm{Ce}$ & 0.000 & 0.000 & 0.000 & 0.000 & - & - & 0.000 & 0.001 & 0.000 & 0.001 & - & - & - & - & - \\
\hline $\operatorname{Pr}$ & - & - & - & - & - & - & 0.000 & 0.000 & 0.000 & 0.001 & - & . & - & - & - \\
\hline Nd & 0.001 & 0.002 & 0.000 & 0.000 & - & 0.006 & 0.001 & 0.001 & 0.002 & 0.002 & 0.004 & - & - & - & - \\
\hline $\mathrm{Sm}$ & 0.000 & 0.014 & 0.003 & 0.009 & - & 0.014 & 0.012 & 0.007 & 0.003 & 0.003 & 0.006 & - & - & 0.004 & - \\
\hline $\mathrm{Eu}$ & - & - & - & - & 0.001 & 0.001 & - & - & 0.000 & 0.000 & - & - & - & 0.000 & - \\
\hline $\mathrm{Gd}$ & 0.024 & 0.071 & 0.065 & 0.088 & 0.026 & 0.040 & 0.099 & 0.083 & 0.065 & 0.033 & 0.010 & 0.004 & 0.003 & 0.018 & 0.001 \\
\hline $\mathrm{Tb}$ & 0.012 & 0.018 & 0.028 & 0.038 & 0.010 & 0.010 & 0.014 & 0.013 & 0.012 & 0.007 & 0.005 & 0.003 & - & 0.002 & - \\
\hline Dy & 0.072 & 0.091 & 0.128 & 0.167 & 0.077 & 0.077 & 0.072 & 0.074 & 0.100 & 0.067 & 0.056 & 0.052 & 0.047 & 0.071 & 0.012 \\
\hline Ho & 0.006 & 0.006 & 0.008 & 0.010 & 0.013 & 0.013 & 0.012 & 0.013 & 0.023 & 0.015 & 0.007 & 0.013 & 0.008 & 0.029 & - \\
\hline $\mathrm{E}_{\mathrm{T}}$ & 0.014 & 0.017 & 0.013 & 0.017 & 0.042 & 0.041 & 0.041 & 0.034 & 0.082 & 0.086 & 0.053 & 0.113 & 0.117 & 0.115 & 0.083 \\
\hline $\mathrm{Tm}$ & 0.002 & 0.003 & 0.002 & 0.001 & - & - & - & - & 0.013 & 0.019 & 0.012 & 0.039 & 0.039 & 0.023 & 0.047 \\
\hline $\mathrm{Yb}$ & 0.011 & 0.017 & 0.010 & 0.012 & 0.022 & 0.032 & 0.028 & 0.019 & 0.086 & 0.170 & 0.125 & 0.481 & 0.402 & 0.226 & 0.596 \\
\hline $\mathbf{L u}$ & 0.000 & 0.000 & 0.000 & 0.000 & 0.002 & 0.003 & 0.007 & 0.006 & 0.014 & 0.025 & 0.010 & 0.093 & 0.121 & 0.027 & 0.115 \\
\hline $\mathrm{Ca}$ & 0.000 & 0.001 & 0.001 & 0.005 & 0.000 & 0.004 & $0.00 \mathrm{~J}$ & 0.003 & 0.003 & 0.007 & - & - & - & 0.006 & 0.012 \\
\hline $\mathrm{Fe}^{3+}$ & 0.008 & 0.000 & 0.002 & 0.004 & - & - & - & - & - & - & - & - & - & - & - \\
\hline $\mathrm{Mn}$ & 0.000 & 0.000 & 0.004 & 0.000 & - & - & - & - & - & - & - & - & - & - & - \\
\hline $\mathrm{Pb}$ & 0.000 & 0.000 & 0.000 & 0.000 & - & - & - & - & - & - & - & - & - & - & - \\
\hline $\operatorname{Sum} A$ site & 0.991 & 0.988 & 0.984 & 1.001 & 1.037 & 1.033 & 1.013 & 1.004 & 0.987 & 0.972 & 1.064 & 1.000 & 1.009 & 1.055 & 1.114 \\
\hline $\mathbf{P}$ & 1.002 & 1.005 & 1.009 & 1.000 & 0.976 & 0.953 & 0.983 & 0.977 & 1.001 & 0.994 & 0.869 & 1.001 & 1.005 & 0.968 & 0.934 \\
\hline $\mathrm{Si}$ & 0.004 & 0.001 & 0.001 & 0.000 & 0.000 & 0.035 & 0.009 & 0.023 & 0.009 & 0.027 & 0.102 & 0.000 & 0.000 & 0.000 & - \\
\hline Sum $T$ site & 1.006 & 1.006 & 1.010 & 1.000 & 0.976 & 0.988 & 0.992 & 1.000 & 1.010 & $1.02\}$ & 0.971 & 1.001 & 1.005 & 0.968 & 0.934 \\
\hline F & 0.003 & 0.006 & 0.000 & 0.000 & - & - & - & - & $=$ & - & - & - & - & - & - \\
\hline 0 & 3.997 & 3.994 & 4.000 & 4.000 & 4.000 & 4.000 & 4.000 & 4.000 & 4.000 & 4.000 & 4.000 & 4.000 & 4.000 & 4.000 & 4.000 \\
\hline
\end{tabular}

Columns: 1 to 4: Annie Claim \#3, this study, 5,6: Demartin et al. (1991), their samples 11 and 6, from alpine veins; 7, 8: Franz et al. (1996), their samples 17329.1 and 14529.1, respectively, from metasediments; 9,10: Forster (1998), his samples 1141-FS and 1157-FS, respectively, from granites; 11 : Jefford (1962), his sample 1, total includes 0.51 wt. $\%$ by ignition loss, from an alkaline granite; 12, 13: Buck et al. (1999), their samples YB1 and YB2, respectively, from a granitic pegmatite; 14: Voloshin \& Pakhomovskii (1986), their sample 2, from a granitic pegmatite; 15: Belolipetskii \& Voloshin (1996), their sample 1, from a granitic pegmatite. 0.00: below detection limit; n.d.: not determined. Compositions reported in wt. \% oxides + fluorine. 

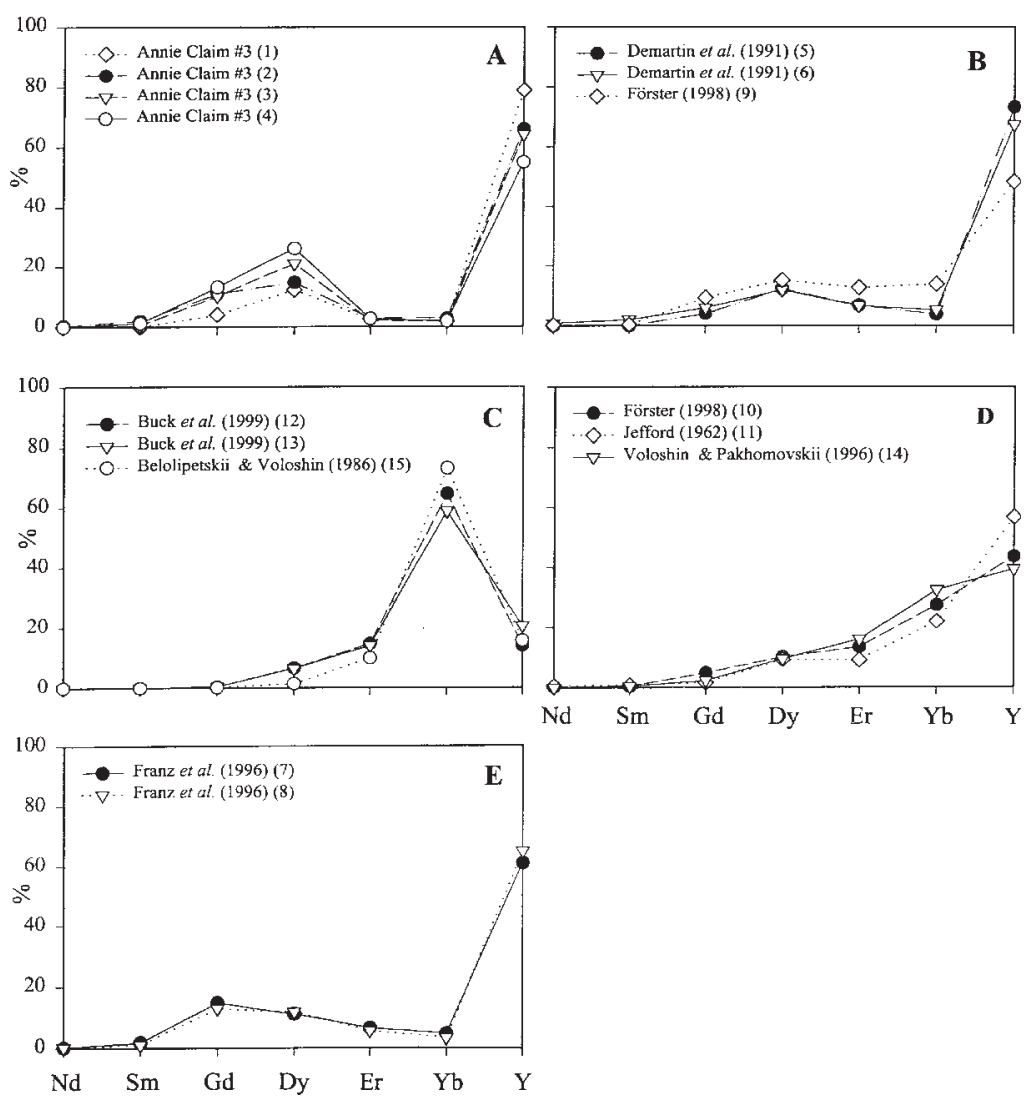

FIG. 1. Concentrations of middle and heavy even-numbered $R E E$ and $\mathrm{Y}$, normalized to a total of 100 , in selected samples of xenotime- $(\mathrm{Y})$ and xenotime- $(\mathrm{Yb})$; numbers in brackets after the references correspond to those of compositions quoted in Table 1.

and Buck et al. (1999). Some of those compositions also show exceptional enrichment in $\mathrm{Er}$ and $\mathrm{Lu}$, but the Dy and Gd contents are invariably low (Table 1, compositions 11 to 15, Figs. 1C, D).

A strong positive $\mathrm{Gd}$ anomaly was recorded by Sahama et al. (1973) in xenotime-(Y) from the Morrua pegmatite, Mozambique, but only in terms of relative abundance compared to other REE; quantitative data were not obtained. Otherwise, moderately Gd-enriched xenotime was encountered only by Franz et al. (1996) in metapelitic lithologies (Table 1, compositions 7 and 8, Fig. 1E).

The selective enrichments in individual HREE do not seem to be related to specific environments that generate xenotime. In contrast, some of the REE tend to correlate in samples of various provenances. A link may possibly exist among the positive anomalies of $\mathrm{Yb}, \mathrm{Er}$ and Lu, which are found mainly in Dy- and Gd-depleted samples. On the other hand, Dy and Gd locally both tend to show an enrichment.

\section{Chondrite-normalized REE abundances}

It is noteworthy that the $\mathrm{Dy}+\mathrm{Gd}$ and $\mathrm{Yb}+\mathrm{Er}+\mathrm{Lu}$ associations suggested above coincide with two of the four REE tetrads, based on the periodicity and rhythmics of ground-state total orbital quantum numbers of free trivalent REE cations (Sinha 1975, and reviewed in Sinha 1983). Expression of this tetrad effect in geological materials was reported by, e.g., Masuda \& Ikeuchi (1979), Masuda et al. (1987) and Masuda \& Akagi (1989), doubted by McLennan (1994) and Pan (1997), but reaffirmed by Bau $(1996,1997)$ and Möller (1997) specifically for mineral assemblages and whole-rock overprints generated in aqueous environments (postmagmatic fluids, hydrothermal solutions, and surface waters).

The tetrad effect is best revealed in the classic chondrite-normalized patterns, shown in Figure 2 for the third- and fourth-tetrad elements (Gd to $\mathrm{Ho}$ and $\mathrm{Er}$ to $\mathrm{Lu}$, respectively) for the compositions listed in Table 1. 

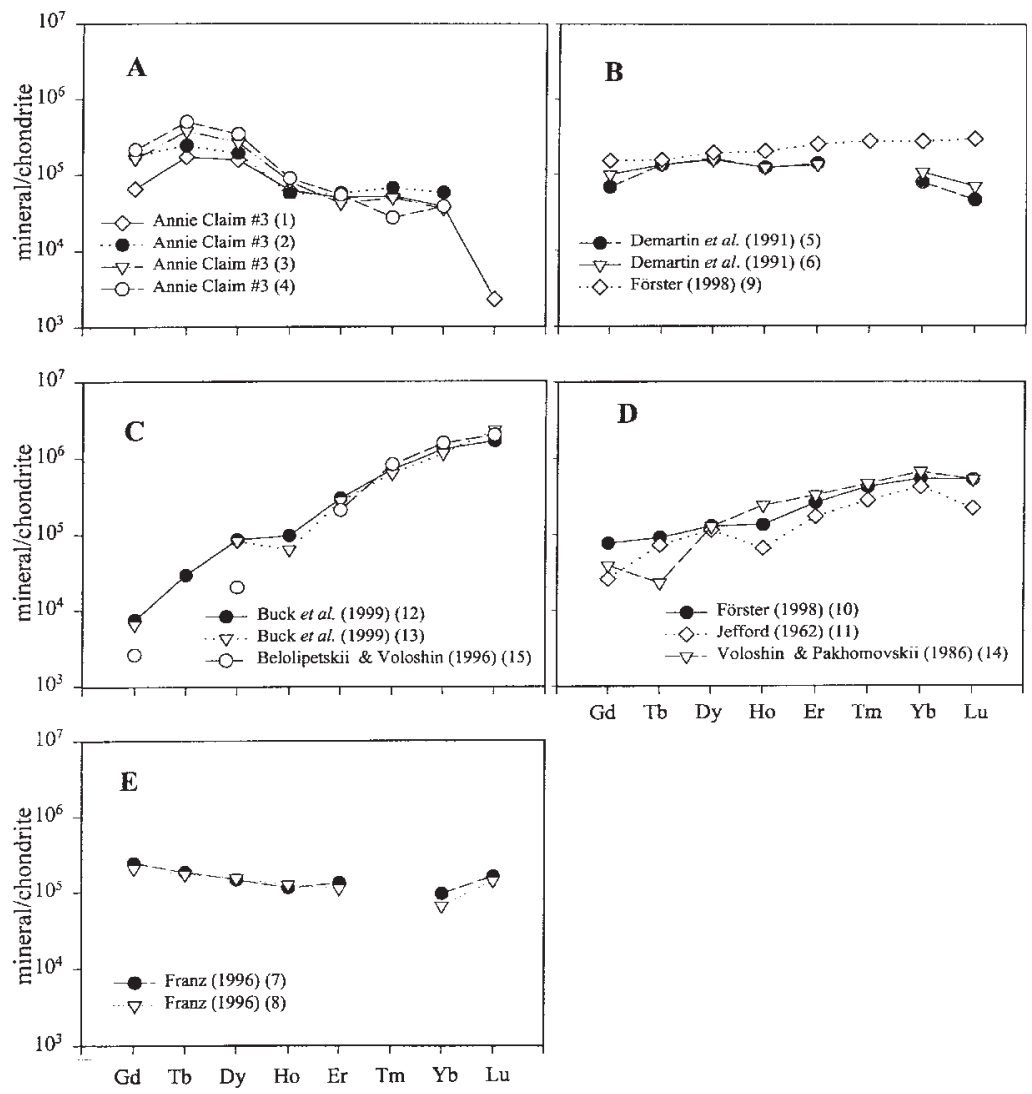

FIG. 2. Chondrite-normalized REE abundances ( $\mathrm{Gd}$ to $\mathrm{Lu}$ ) in compositions of selected samples of xenotime-(Y) and xenotime-( $\mathrm{Yb})$; numbers in brackets after the references correspond to those of compositions quoted in Table 1. The patterns are grouped as in Figure 1 .

The tetrad effect is apparently well expressed in xenotime-(Y) from the Annie Claim \#3 pegmatite, from alpine veins (Demartin et al. 1991), and from an alkaline pegmatite (Jefford 1962), and in xenotime-(Yb) from the Shatford Lake pegmatite group (Buck et al. 1999) (Figs. 2A, B, C). In contrast, it is not observed in samples from granites (Förster 1998) and metamorphic rocks (Franz et al. 1996) (Figs. 2D, E). Xenotime-(Yb) from granitic pegmatites of Kola Peninsula generates irregular (Voloshin \& Pakhomovskii 1986) or smoothlooking (Belolipetskii \& Voloshin 1996) patterns (Figs. 2C, D).

Magmas consolidating into more or less highly fractionated granitic pegmatites do not rank with aqueous systems sensu stricto, but they differ distinctly from plutonic batches of granitic melts by considerable enrichment in $\mathrm{H}_{2} \mathrm{O}$, promoted by the presence of $\mathrm{F}, \mathrm{B}, \mathrm{P}$ and Li (e.g., London 1986a, b, 1990). Experimental evidence shows that homogeneous residual F,B,P,Li- rich pegmatite-forming melts may contain up to $\sim 15$ wt.\% (approx. 40 vol.\%) dissolved $\mathrm{H}_{2} \mathrm{O}$ (London et al. 1989). The Annie Claim \#3 pegmatite could not attain this experimentally established maximum, as it is very poor in $\mathrm{P}$ and $\mathrm{B}$, but it must have crystallized from a $\mathrm{Li}$ and F-rich and consequently $\mathrm{H}_{2} \mathrm{O}$-rich magma, as indicated by the abundance of $\mathrm{Li}$ - and F-rich micas. In general, pegmatite-forming magmas should qualify as substantially aqueous systems with respect to REE behavior ( $c f$. Bau 1996), despite being phase-homogeneous throughout most of their consolidation (before they become volatile-oversaturated and exsolve a supercritical fluid; e.g., London et al. 1989).

The number of data summarized in Table 1 and represented in Figures 1 and 2 is not sufficiently significant to substantially contribute to the argument for or against the geological expression of the tetrad effect, all the more that they are restricted to only the heavy half of the REE spectrum. Nevertheless, the coincidence of 
the apparent tetrad effect with xenotime formed from aqueous environments is unmistakable. Analytical problems inherent to inductively-coupled-plasma and sparksource mass spectrometries as a cause of unusual REE patterns (McLennan 1994) do not apply, as the data considered here were generated by electron-microprobe analysis in different laboratories, using in part different analytical techniques and different methods of calibration. Virtually perfect stoichiometry of the Annie Claim \#3 and Shatford Lake xenotime also indicates that the analytical procedures are above reproach.

\section{Comparison of the absolute concentration and chondrite-normalized patterns}

The differences between some of the patterns of Figure 1 and their counterparts in Figure 2 are remarkable, but generally expectable because of the different methods of normalization. For example, the positive Gd anomalies in the samples of Franz et al. (1996), the positive Dy anomalies in the alpine-vein samples (Demartin et al. 1991) and the positive $\mathrm{Yb}$ anomalies in the samples of Förster (1998), Jefford (1962) and Voloshin \& Pakhomovskii (1986) are preserved in the chondrite-normalized patterns. In contrast, the moderate Dy anomaly in sample 1141-FS (Förster 1998) is barely noticeable in the chondrite-normalized plot, the very prominent enrichment in $\mathrm{Yb}$ in samples of Belolipetskii \& Voloshin (1996) and Buck et al. (1999) is balanced by $\mathrm{Tm}$ and $\mathrm{Lu}$, and a prominent $\mathrm{Tb}$ maximum dominates the chondrite-normalized plots of the Annie Claim \#3 samples, overshadowing the wt.\%dominant enrichment in Dy.

The tetrad effect is an intrinsic property rooted in the periodicity of atomic structure of the REE, probably leading to differential complexation of $R E E$ in highly evolved, ligand-rich and hydrous granitic and pegmatite-forming melts, and in hydrothermal fluids (Bau 1996). In this context, the tetrad effect may explain the segmented REE abundances in geological products of the above environments. However, no data or hypotheses are currently available to explain the observed enrichment and depletion in individual REE. The available literature on experimental studies deals only with lowtemperature hydrothermal and surface conditions ( $c f$. Möller 1983, Byrne \& Li 1995, among others). Selective complexing and differential stabilities of the complexes of individual REE could be responsible, as proposed by Gramaccioli \& Pezzotta (1997) and Pezzotta et al. (1999). Broadly based experimental evidence on REE behavior with inorganic ligands at conditions corresponding to consolidation of hydrous and volatile-rich pegmatite-forming melts, supercritical fluids and high-temperature hydrothermal solutions is desirable. The recent work of Wood (e.g., 1990, 1996) is most promising in this respect.

\section{ACKNOWLEDGEMENTS}

This work was in part excerpted and in part upgraded from the B.Sc. (Honours) thesis of MM, supported by NSERC Research, Major Installation and Equipment Grants to PČ. The review and editorial improvements by R.F. Martin are gratefully acknowledged.

\section{REFERENCES}

ÅMLI, R. \& GRIFFIN, W.L. (1975): Microprobe analysis of REE minerals using empirical correction factors. Am. Mineral. 60, 599-606.

BAU, M. (1996): Controls on the fractionation of isovalent trace elements in magmatic and aqueous systems: evidence from $\mathrm{Y} / \mathrm{Ho}, \mathrm{Zr} / \mathrm{Hf}$, and lanthanide tetrad effect. Contrib. Mineral. Petrol. 123, 323-333.

(1997): The lanthanide tetrad effect in highly evolved felsic igneous rocks - a reply to the comment by Y. Pan. Contrib. Mineral. Petrol. 128, 409-412.

Belolipetskit, A.P. \& Voloshin, A.V. (1996): Yttrium and rare earth element minerals of the Kola Peninsula, Russia. In Rare Earth Minerals: Chemistry, Origin and Ore Deposits (A.P. Jones, F. Wall \& C.T. Williams, eds.). Chapman and Hall, London, U.K. (311-326).

Buck, H.M., COOPER, M.A., ČERnY, P., Grice, J.D. \& HaWTHORNE, F.C. (1999): Xenotime-(Yb), $\mathrm{YbPO}_{4}$, a new mineral species from the Shatford Lake pegmatite group, southeastern Manitoba, Canada. Can. Mineral. 37, 1303-1306.

Byrne, R.H. \& Li, Biquiong (1995): Comparative complexation behaviour of the rare earths. Geochim. Cosmochim. Acta 59, 4575-4589.

Černy, P., Trueman, D.L., Ziehlke, D.V., Goad, B.E. \& Paul, B.J. (1981): The Cat Lake - Winnipeg River and Wekusko Lake pegmatite fields, Manitoba. Manitoba Dep. Energy and Mines, Mineral. Resources Div., Econ. Geol. Rep. ER80-1.

Demartin, F., Pilati, T., Diella, V., Donzelli, S., Gentile, P. \& Gramaccioli, C.M. (1991): The chemical composition of xenotime from fissures and pegmatites in the Alps. Can. Mineral. 29, 69-75.

FÖRSTER, H.-J. (1998): The chemical composition of REE-YTh-U-rich accessory minerals in peraluminous granites of the Erzgebirge-Fichtelgebirge region, Germany. II. Xenotime. Am. Mineral. 83, 1302-1315.

\& RHEDE, D. (1995): Composition of monazite and xenotime from the Fichtelgebirge granites - an electron microprobe study. Ber. Deutsch. Mineral. Gesellschaft 1, 68 .

Franz, G., Andrehs, G. \& Rhede, D. (1996): Crystal chemistry of monazite and xenotime from SaxothuringianMoldanubian metapelites, NE Bavaria, Germany. Eur. J. Mineral. 8, 1097-1118. 
Gramaccioli, C.M. \& Pezzotta, F. (1997): Geochemistry of yttrium with respect to the REE elements in pegmatites. Abstr. 1st Int. Workshop on Petrology, Rare Minerals and Gemstones of Shallow-Depth Pegmatites. Museo di Storia Naturale di Milano, 8.

JEFFORD, G. (1962): Xenotime from Rayfield, northern Nigeria. Am. Mineral. 47, 1467-1472.

LONDON, D. (1986a): Magmatic-hydrothermal transition in the Tanco rare-element pegmatite: evidence from fluid inclusions and phase-equilibrium experiments. Am. Mineral. 71, 376-395.

(1986b): Formation of tourmaline-rich gem pockets in miarolitic pegmatites. Am. Mineral. 71, 396-504.

(1990): Internal differentiation of rare-element pegmatites: a synthesis of recent research. In Ore-Bearing Granite Systems; Petrogenesis and Mineralizing Processes (H.J. Stein \& J.L. Hannah, eds.). Geol. Soc. Am., Spec. Pap. 246, 35-50.

Morgan, G.B., VI \& Hervig, R.L. (1989): Vaporundersaturated experiments on Macusani glass $+\mathrm{H}_{2} \mathrm{O}$ at $200 \mathrm{MPa}$, and the internal differentiation of granitic pegmatites. Contrib. Mineral. Petrol. 102, 1-17.

Masau, M. (1999): Mineralogy and Geochemistry of the Annie Claim No. 3 Pegmatite Pod at Greer Lake, Southeastern Manitoba. B.Sc. thesis, Univ. of Manitoba, Winnipeg, Manitoba.

MAsudA, A. \& AKagi, T. (1989): Lanthanide tetrad effect observed in leucogranites from China. Geochem. J. 23, 245253.

\& IKEUCHI, Y. (1979): Lanthanide tetrad effect observed in marine environment. Geochem. J. 13, 19-22.

Kawakami, O., Dohmoto, Y. \& Takenaka, T. (1987): Lanthanide tetrad effect in nature: two mutually opposite types, W and M. Geochem. J. 21, 119-124.

MCLENNAN, S.M. (1994): Rare earth element geochemistry and the "tetrad" effect. Geochim. Cosmochim. Acta 58, 20252033.

MöLLER, P. (1983): Lanthanoids as a geochemical probe and problems in lanthanoid geochemistry: distribution and behaviour of lanthanoids in non-magmatic phases. In Systematics and the Properties of the Lanthanides (S.P. Sinha, ed.). NATO Advanced Study Inst., Ser. C 109. Reidel, Dordrecht, The Netherlands (561-616).

(1997): Rare earth element and yttrium fractionation caused by fluid migration. J. Czech Geol. Soc. 42, 43 (abstr.).

NAGY, G. (1993): "Quick" method for REE mineral analysis by EMPA. Symp. Rare Earth Minerals: Chemistry, Origin and Ore Deposits. Mineral. Soc. and Nat. Hist. Museum (London), Abstr. (94-96).
PAN, YuANMING (1997): Controls on the fractionation of isovalent trace elements in magmatic and aqueous systems: evidence from $\mathrm{Y} / \mathrm{Ho}, \mathrm{Zr} / \mathrm{Hf}$, and lanthanide tetrad effect a discussion of the article by M. Bau (1996). Contrib. Mineral. Petrol. 128, 405-408.

Pezzotta, F., Diella, V. \& Guastoni, A. (1999): Chemical and paragenetic data on gadolinite-group minerals from Baveno and Cuasso al Monte, southern Alps, Italy. Am. Mineral. 84, 782-789.

Pouchou, J.-L. \& Pichoir, F. (1984): A new model for quantitative analysis. 1. Application to the analysis of homogeneous samples. Recherche Aérosp. 5, 47-65.

\& __ (1985): "PAP” (phi-rho-Z) procedure for improved quantitative microanalysis. In Microbeam Analysis (J.T. Armstrong, ed.). San Francisco Press, San Francisco, California (104-106).

Sabourdy, G., Sagon, J.-P. \& Pastier, P. (1997): La composition chimique du xénotime en Limousin, Massif Central, France. Can. Mineral. 35, 937-946.

SAhama, T.G., von Knorring, O. \& RehtiJ̈̈rvi, P. (1973): Xenotime from Morrua, Mozambique. Bull. Geol. Soc. Finland 45, 67-71.

SinHA, S.P. (1975): Gadolinium break, tetrad and double-double effects were there, what next. Helv. Chim. Acta 58, 1978-1983.

(1983): Inclined W systematics of the lanthanides. In Systematics and Properties of the Lanthanides (S.P. Sinha, ed.). NATO Advanced Study Inst., Ser. C 109. Reidel, Dordrecht, The Netherlands (71-122).

TAYloR, S.R. \& McLennan, S.M. (1985): The Continental Crust: its Composition and Evolution. Blackwell Sci. Publ., London, U.K.

Vlasov, K.A., ed. (1966): Geochemistry and Mineralogy of Rare Elements and Genetic Types of Their Deposits. I. Geochemistry of Rare Elements. Israel Program Sci. Translations, Jerusalem, Israel.

Voloshin, A.V. \& PAKHomovskiI, YA.A. (1986): Minerals and Evolution of Mineral Formation in The Amazonitic Pegmatites of The Kola Peninsula. Nauka Press, Leningrad, Russia (in Russ.).

Wood, S.A. (1990): The aqueous geochemistry of rare-earth elements and yttrium. 2. Theoretical predictions of speciation in hydrothermal solutions to $350^{\circ} \mathrm{C}$ at saturation water vapor pressure. Chem. Geol. 88, 99-125.

(1996): Determination of stability constants for REE complexes at elevated temperature; acetate and chloride complexes of $\mathrm{Nd}$ to $300^{\circ} \mathrm{C}$. Int. Geol. Congress (Beijing), Abstr. 3, 34.

Received July 3, 1999, revised manuscript accepted June 10, 2000. 